\title{
The Relationship Between Less Consumption of Vegetables and Fruit With Overweight Incidence at Productive Age (15-64 Years) in Parung District, Bogor Regency
}

\author{
Putri Risa Sonia \\ Master in Public Health, Faculty of Public Health, Muhammadiyah University of Jakarta \\ K.H. Ahmad Dahlan St, Cireundeu, Ciputat, South Jakarta, 15419 \\ Email: risasoniaaa@gmail.com
}

\begin{abstract}
Obesity/overweight is a nutritional problem that has an impact on long-term health. An overweight person has a risk of developing diabetes, ischemic heart disease, and cancer. The purpose of this study is to analyze the relationship of factors of lack of vegetable and fruit consumption with the incidence of overweight at the productive age (15-64 years) in Parung Subdistrict. This study uses secondary data, a quantitative type with a cross-sectional study design. The sample of this study is 142 people of productive age (15-64 years) using simple random sampling, data collection was conducted in conjunction with vaccine surveys in Parung Subdistrict conducted by officers and applied $3 M$. The results showed that there was no relationship between lack of consumption of vegetables and fruits with overweight events. Factors lacking fruit and vegetable consumption are not the main factors causing overweight, many other factors that can affect, such as genetic factors, lack of physical activity, drugs, or hormonal. Genetic factors usually affect 40-50\% if one of the people has a history of overweight or obesity, but if both parents have a history of obesity it will affect 70-80\% of the next offspring. Factors lack of physical activity leads to less maximal energy expenditure, it is highly recommended at least 30 minutes a day of activity. Drug factors such as steroid drugs that are often consumed in the long term to treat asthma, osteoarthritis, and allergies, can lead to increased appetite and increase the risk of overweight or obesity. Hormonal factors commonly associated with obesity are hormones such as leptin, ghrelin, thyroid, insulin, and estrogen, and regular medications with hormonal are often associated with the use of contraceptives such as birth control pills or injectable birth control.
\end{abstract}

Keywords: Fruits and Vegetables, Overweight, Productive 


\section{INTRODUCTION}

Currently, Indonesia is faced with three burdens of nutritional problems or commonly referred to as the triple burden. The triple burden in question is stunting, wasting, and overweight or obesity, as well as micronutrient deficiencies such as iron deficiency which can cause anemia. The phenomenon of overweight or obesity is a serious threat because until now overweight or obesity is one of the main risk factors for various degenerative diseases (1). Overweight and obesity are some of the leading causes of death in the world's population compared to underweight or commonly called wasting (2). The increasing number of overweight and obesity will increase the risk of diabetes mellitus, heart disease, stroke, and certain cancers. A person who is overweight or obese will increase the risk by $44 \%$ of developing diabetes, $23 \%$ of developing ischemic heart, and $7 \%-4 \%$ of developing cancer (3). Being overweight and obese not only have an impact on physical health, but also social and economic problems. Various degenerative diseases caused by overweight or obesity contributed to various disabilities, it was noted that the economic burden spent on disability by degenerative diseases was 476 million and 240 million DALYs (Disability Adjusted Life Years) for each degenerative disease (4).

From 1975 to 2016 there was a threefold increase in the prevalence of overweight and obesity in the world (5). In 2016 there were 1.9 billion people of productive age who were overweight, and 650 million of them were obese (5)(6). The majority of developed countries in the west have a high prevalence of overweight and obesity, some western countries with the highest prevalence of overweight are the United States (38.2\%), Mexico (32.4\%), New Zealand (30\%), and Hungary (30\%) (7). If this problem persists, it is estimated that as many as 2.7 billion adults will be overweight and more than 1 billion people will be obese by 2025 (8). In 2018, Indonesia recorded a prevalence of overweight and obesity of $21.8 \%$, based on the overweight category, Indonesia had a prevalence of $14.6 \%$ and the province with the highest prevalence of overweight was East Kalimantan as much as $16.5 \%$, for the province of West Java it had a prevalence overweight which is quite high as much as $14.4 \%$ (9) (10). The highest prevalence for overweight and obesity in the province of West Java is Bekasi (23.4\%), Depok (21\%), and Bogor (20.1\%) (11), previous research has conducted that there is a prevalence of overweight in the working area of the Sub-district Health Center Parung as much as $38.3 \%$. Based on Kusteviani's research, there are $67.04 \%$ of productive age people in Banyumas Regency who have excess body weight or BMI 25 (12). The results of Arum's research showed that $45.6 \%$ of people of productive age in the working area of the Jagir District Health Center were overweight (overweight and obese) (13).

Many factors that cause overweight or obesity include genetic factors, environment, drugs, hormones (3). Genetic factors usually affect $40-50 \%$ if one parent has a history of being overweight or obese, but if both parents have a history of obesity it will affect $70-80 \%$ of the next offspring (2). 
Environmental factors for overweight or obesity usually include dietary factors and activity patterns. Indonesia's population growth accompanied by an increase in the number of productive age population and the pace of urbanization brings a shift in lifestyle and food preferences, Urbanization and income growth drive changes in nutrition to create economies of scale sufficient, encourage the growth of fast food outlets and supermarkets. This is also believed to encourage people's lifestyles to become less mobile and eat more delicious foods (14), usually, people who are overweight or obese have poor eating patterns, such as frequent eating fast food and less consumption of vegetables and fruit. Based on Riskesdas data in 2018, $40.1 \%$ of Indonesians consumed sweet foods, $41.7 \%$ consumed fatty foods, $7.8 \%$ consumed instant food, $95.4 \%$ consumed fewer vegetables and fruit, and $33.5 \%$ lacked activity. physical (9). The average community consumption of vegetables is 70.0 grams/person/day (recommended 250 grams of vegetables per day) and fruit consumption is 38.8 grams/person/day (recommended 150 grams of fruit per day), and the total average consumption of vegetables and fruit of the Indonesian people as much as 108.8 grams/person/ day (recommended 400 grams per day), overall this figure is still said to be low so that it does not meet the needs of fiber, vitamins, and minerals (15)(16).

Research conducted by Yanto, et al. showed that there was a relationship between lack of eating vegetables and fruit with the incidence of overnutrition or overweight in the Perawang area, Riau. supplementary food, carbohydrate consumption patterns, or rice and side dishes are the main food staples (17). Research conducted by Bey et al showed similar results that there was a relationship between lack of eating vegetables and fruit with the incidence of overweight in Semarang, this was due to practical eating patterns, such as consuming lots of fast food because it was easy to get, as well as other reasons, namely the taste of vegetables and fruit. which is less tasty, some even taste bitter(18). According to Eryani et al's research, it is inversely proportional to two previous studies, Eryani et al's research states that there is no relationship between vegetable and fruit consumption with the incidence of excess body weight in the Limpung, Batang area due to sufficient physical activity, sufficient physical activity can burn fat. is in the body(19).

Given that the prevalence of overweight in Parung District is still quite high and the rate of urbanization is driving changes in nutrition, this has prompted researchers to conduct research that relates factors to lack of consumption of vegetables and fruits with overweight events. This study specifically aims to analyze the relationship between factors of less consumption of vegetables and fruit with the incidence of overweight in productive age (15-64 years) in Parung District.

\section{METHOD}

This study is quantitative, using secondary data for Surveillance of PTM (NonCommunicable Diseases) at the Health Center of Parung Sub-district, data collection for Surveillance 
of PTM (Non Communicable Diseases) was carried out from February to May 2021. Data collection on PTM Surveillance (Non-Communicable Diseases) coincided with vaccination data collection. Covid-19, Vaccination data collection, and PTM surveillance questionnaire interviews by the health protocol (Using hand sanitizer, Using the mask, Keeping distance). The data was taken by health workers from the Covid-19 group at the Parung Health Center who had been vaccinated. This study used a cross-sectional study design because the secondary data selected as research data were selected at one time. The sample of this study was 142 people of productive age (15-64 years) using simple random sampling (random drawing according to the serial number of secondary data). The analysis of this study was conducted in May 2021 using univariate analysis to see prevalence and bivariate chi-square analysis

$(\alpha$ $0.05)$.

\section{RESULT AND DISCUSSION}

Table 1. Characteristics of Respondents

\begin{tabular}{lcc}
\hline \multicolumn{1}{c}{ Variable Name } & n & \% \\
\hline Level of Education & 1 & 0.7 \\
Not School & 39 & 27.5 \\
Primary School and Junior High School & 82 & 57.7 \\
Senior High School & 9 & 6.3 \\
Diploma & 11 & 7.7 \\
Bachelor & & 2.1 \\
Job & 3 & 12.7 \\
Farmer & 18 & 2.1 \\
Merchant/Enterpreneur & 3 & 1.4 \\
Labor & 2 & 38 \\
Lecture/Teacher & 54 & 19 \\
Housewife & 27 & 2.1 \\
Employee & 3 & 22.5 \\
Not yet Working & 32 & 43 \\
Student/Collage Student & & 57 \\
Sex & 61 & \\
Male & 81 & 62.7 \\
Female & & 37.3 \\
Less Consumption of Vegetables \& Fruit & 89 & 37.3 \\
Yes & 53 & 62.7 \\
No & & \\
BMI & 53 & \\
Overweight $\geq 25$ BMI & 89 & \\
Normal <25 BMI & & \\
\hline & & \\
\hline
\end{tabular}

Based on table 1, the majority of the 142 level were senior high school/high school with a total of 89 people (57.7\%), while most of the respondents occupations were housewives as many as 54 people (38\%). The majority of the sex many as 81 people (57\%), while the male respondents were 61 people $(43 \%)$. There were 89 people $(62.7 \%)$ of respondents who had less consumption of vegetables and fruit and as many as 89 people (62.7\%) had a normal Body Mass Index (BMI) $<25$ 
Table 2. The Relationship between Less Consumption of Vegetables and Vegetables with Overweight Incidence at Productive Age (15-64 years) in Parung District, Bogor Regency

\begin{tabular}{|c|c|c|c|c|c|c|c|c|}
\hline \multirow{3}{*}{$\begin{array}{c}\text { Less } \\
\text { Consumption } \\
\text { of Vegetables } \\
\text { \& Fruit }\end{array}$} & \multicolumn{4}{|c|}{$\begin{array}{c}\text { Overweight Incidence } \\
\end{array}$} & \multirow{2}{*}{\multicolumn{2}{|c|}{ Total }} & \multirow{3}{*}{$\begin{array}{c}\text { OR }(95 \% \\
\text { CI })\end{array}$} & \multirow[t]{3}{*}{$\mathbf{P v}$} \\
\hline & \multicolumn{2}{|c|}{ Overweight $\geq 25 \mathrm{BMI}$} & \multicolumn{2}{|c|}{ Normal < 25 BMI } & & & & \\
\hline & $\mathbf{N}$ & $\%$ & $\mathbf{N}$ & $\%$ & $\mathbf{N}$ & $\%$ & & \\
\hline Yes & 36 & 40.4 & 53 & 59.6 & 89 & 100 & & \\
\hline No & 17 & 32.1 & 36 & 67.9 & 53 & 100 & $1.4(0.7-2.9)$ & 0.413 \\
\hline Total & 53 & 37.3 & 89 & 62.7 & 142 & 100 & & \\
\hline
\end{tabular}

Based on Table 2, the results of the analysis of the relationship between less consumption of vegetables and fruits with the incidence of overweight were found that the majority of respondents who had less consumption of vegetables and fruit were 36 people $(40.4 \%)$ who were overweight. Meanwhile, among respondents who did not consume less vegetables and fruit, there were 17 people (32.1\%) who were overweight. The results of the Chi-Square statistical test with the Continuity Correction test (a) obtained $\mathrm{p}$ value $=0.413$, it can be concluded that there is no difference between less consumption of vegetables and fruits and the proportion of overweight events lacking vegetables and fruit (it can also be concluded: there is no significant relationship between less less consumption of vegetables and fruit with the incidence of overweight).

Based on the results of the analysis, it was found that there was no relationship between the lack of consumption of vegetables and fruits with the incidence of overweight in the productive age (15-64 years). The results of this study are in line with the research of Eryani, et al which stated that there was no relationship between vegetable and fruit consumption with the incidence of overweight in the Limpung, Batang area due to sufficient physical activity, sufficient physical activity can burn fat in the body (19). This study also has the same results as the study of Yuliah, et al in 2017 in the Mamuju area which stated that there was no relationship between vegetable and fruit consumption and the incidence of excess body weight with a p value 0.872 (25).

Lack of vegetables and fruit is not the main factor causing overweight, there are many other factors that cause overweight that are not studied by researchers. Factors that cause overweight or obesity that are not studied by researchers are genetic factors, lack of physical activity, drugs or hormones (3). Genetic factors usually affect $40-50 \%$ if one parent has a history of being overweight or obese, but if both parents have a history of obesity it will affect $70-80 \%$ of the next offspring (2), this statement is also reinforced by the research of Wijaya, et al. in 2020 which has the result that there is a relationship between overweight and genetics, especially in mothers. in the discussion stated that respondents who have a higher BMI tend to have mothers with a higher BMI with a proportion of $81.7 \%(20)$. 
Lack of physical activity is one of the other factors for overweight or obesity. Based on the research of Nugroho, et al in 2018 which stated that there was a relationship between lack of physical activity and the incidence of overweight in students in Manado (21), and the research of Putri et al in 2017 stated the same thing where there was a significant relationship between lack of physical activity and the incidence of overweight. Those who have a habit of lack of physical activity will have 2.53 times the chance of being overweight $(\mathrm{OR}=2.53)(22)$. One quarter of Indonesia's population belongs to the group that lacks physical activity with a prevalence of $33.5 \%$, lack of physical activity causes less than maximal energy expenditure (3), it is highly recommended that a minimum of 30 minutes a day of activity, cumulatively in a week as much as 150 minutes of physical activity, This is recommended to burn calories and prevent excessive weight gain (23).

Drugs or hormonal factors are other factors that cause overweight or obesity. Steroid drugs are often taken in the long term to treat asthma, osteoarthritis, and allergies, can cause an increase in appetite and increase the risk of being overweight or obese. The drug valproate that causes fat accumulation in several areas of the body is caused by glucocorticoids, besides insulin drugs in diabetics can also cause weight gain, it aims to minimize the occurrence of hypoglycemia, diabetic patients who are given insulin with a sulfonylurea and thiazolidinedione eat will improve the performance of PRAY receptors. -y and increases endogenous insulin release (24).

The hormones commonly associated with obesity are hormones such as leptin, gherin, thyroid, insulin, and estrogen, and hormonal drugs are often associated with the use of contraceptives such as birth control pills or birth control injections. (3). Based on information from the Head of $\mathrm{MCH}$ in the Parung Health Center, the majority of mothers in Parung sub-district still use hormonal contraception, and the most widely used are injections and pills. For mothers in Ponjanan, there was an increase in body weight of $69.57 \%$ after using contraceptive drugs (25) this may be caused by the hormone progesterone which facilitates the conversion of carbohydrates and sugar into fat, so that the fat at the bottom of the skin increases, not only that the hormone progesterone It also causes an increased appetite and lowers physical activity, as a result the consumption of contraceptive drugs can cause excess body weight (26)(27).

The results of the analysis in this study are not related with the research by Yanto, et al, which showed that there was a relationship between lack of eating vegetables and fruits with the incidence of overnutrition or overweight in the Perawang area, Riau. respondents have poor eating habits, where there is a lack of consumption of vegetables and fruit in the area, this happens because respondents in the Perawang area, Riau consider that fruit is an expensive food and vegetables are only as additional food, consumption patterns of carbohydrates or rice and side dishes become the main staple food (17). The results of other studies that are not in line with other research, namely Bey et al.'s research, which showed that there was a relationship between lack of eating vegetables and fruits with the incidence of 
overweight in Semarang (18). Although this study had unrelated results, from 53 respondents who were overweight, more than half or as many as 36 overweight respondents had a habit of consuming less vegetables and fruit. This can indirectly state that less consumption of vegetables and fruit is indeed a risk factor for overweight, although it is not a major factor. Another thing that causes an imbalance in consuming vegetables and fruits is their practicality. Usually, foods based on vegetables and fruit must be processed first and take a long process, this is what shifts changes in people's eating patterns. Most of the wheat-based food consumption is in the form of practical and easy-to-process foods such as noodles, bread, and various other cakes, so that every company/organization must be more innovative in order to be able to produce food products with good quality, cheaper prices and better service. (28)(29).

The most underlying of the factors above is knowledge. A person performs a behavior because it is based on 4 things, namely thoughts and feelings, references and references from someone, resources, and socio-culture. One form of thinking and feeling is knowledge. A person will behave based on several considerations obtained from his level of knowledge (30). Individuals prefer something that is known or known beforehand than that which he does not know or know. Most people who are overweight because they do not know about nutritional knowledge and what the GENTAS program or the contents of my plate are for and what are the benefits, so it can be concluded that someone's interest in the program is motivated by someone's knowledge of nutritional status or nutritional knowledge. (3)(30). Every research has limitations, as well as in this study. In this study, the researcher is aware of the many limitations and shortcomings, these limitations and shortcomings will affect the results of the study. Among the limitations are 1) Limitations in finding renewable data sources on background data and researchers mostly use data sources from the last 2-5 years as background data. So that the background data does not describe the current state of renewables. 2) The type of data obtained is secondary data which is measured directly by puskesmas officers, this may lead to the possibility of irrelevant data or omissions in measuring and filling data. 3) On the PTM Surveillance form, the variables that are asked with closed questions are subjective, so that the possibility of making respondents choose answers according to their wishes.

\section{CONCLUSION AND SUGGESTIONS}

Based on the results of this study, the proportion of less consumption of vegetables and fruit was $62.7 \%$ and the proportion of respondents with overweight incidence was $37.3 \%$. The results of the bivariate analysis obtained $\mathrm{p}$ value $=0.413$, so it can be concluded that there is no difference in the proportion of overweight events between less consumption of vegetables and fruit and no less vegetables and fruit (it can also be concluded: there is no significant relationship between less consumption of vegetables and fruits and the incidence of overweight) . 
It is recommended for the Puskesmas Parunng to increase promotive and preventive activities in all types of health fields, as well as to use this research as review material and additional literature on factors that can affect weight gain in the people of Parung District.

\section{REFERENCES}

1. Badan Ketahanan Pangan. Kebijakan Strategi Ketahanan Pangan \& Gizi. Jakarta: Sekertariat Dewan Ketahanan Pangan, Kementerian Pertanian.; 2019.

2. Kementerian Kesehatan RI. Epidemi Obesitas [Internet]. Jurnal Kesehatan. Jakarta: Kementerian Kesehatan RI; 2018. p. 1-8. Available from: http://www.p2ptm.kemkes.go.id/ dokumen$\mathrm{ptm} /$ factsheet-obesitas-kit-informasi-obesitas

3. Kementerian Kesehatan RI. Panduan Pelaksanaan Gerakan Nusantara Tekan Angka Obesitas (GENTAS) [Internet]. Http://P2Ptm.Kemkes.Go.Id/Dok umen-Ptm/Panduan-Gentas. Jakarta: Kementerian Kesehatan RI; 2017. p. 6-16. Available from: http://p2ptm.kemkes.go.id/doku men$\mathrm{ptm} /$ panduan-gentas

4. Bloom, D. E., Chen, S., McGovern, M. E., Prettner, K., Candeias, V., Bernaert A, \& Cristin S. Economics of non-communicable diseases in Indonesia. Geneva: World Economic Forum and Harvard School of Public Health; 2015. 1- 13 p.

5. WHO. Obesity and overweight [Internet]. WHO.int. 2020 [cited 2021 May 17]. Available from: https://www.who.int/news-room/fact-sheets/detail/obesity-and-overweight

6. World Obesity Federation. Prevalence of Obesity [Internet]. WorldObesity.org. [cited 2021 May 18]. Available from: https://www.worldobesity.org/ab out/about-obesity/prevalence-of-obesity

7. Organisation for Economic Co-operation and Development (OECD). Policy insights [Internet]. 2017 [cited 2021 May 17]. Available from: www.oecd.org/health/obesity-update.htm

8. Hales CM, Carroll MD, Fryar CD, Ogden CL. Prevalence of Obesity and Severe Obesity Among Adults: United States, 2017-2018 Key findings Data from the National Health and Nutrition Examination Survey [Internet]. 2017 [cited 2021 May 18]. Available from: https://www.cdc.gov/nchs/produc ts/index.htm.

9. Badan Penelitian dan Pengembangan. RISET KESEHATAN DASAR. Jakarta: Kementria Kesehatan RI; 2018.

10.Kementerian Kesehatan RI. Buku saku pemantauan status gizi. Buku saku pemantauan status gizi tahun 2017. Jakarta: Kementerian Kesehatan RI; 2018. 7-11 p.

11.Dinas Kesehatan Provinsi Jawa Barat. Profil Kesehatan Dinas Kesehatan Provinsi Jawa Barat 2017. Diskes Jabarprov. Bandung: Dinas Kesehatan Provinsi Jawa Barat; 2017. 52 p.

12.Kusteviani F. Factors Associated with Abdominal Obesity in the Productive Age in Surabaya. J Berk Epidemiol. 2015;3(1):45. 
13.Arum YTG. Hipertensi pada Penduduk Usia Produktif (15-64 Tahun). HIGEIA (Journal Public Heal Res Dev. 2019;3(3):345-56.

14.Cargill. Pertumbuhan Populasi, Urbanisasi dan Melambungnya Kebutuhan Pangan, Sementara Stok Pangan Kian Terbatas akan Pengaruhi Pasokan Pangan Masa Depan di Asia [Internet]. www.cargill.co.id. Jakarta; 2019 [cited 2021 May 18]. Available from: https://www.cargill.co.id/id/2019/population-growth-rapid-rural-_id

15.Prihatini H dan. Gambaran Konsumsi Sayur dan Buah Penduduk Indonesia dalam Konteks Gizi Seimbang: Analisis Lanjut Survei Konsumsi Makanan Individu ( SKMI ) 2014 FRUITS AND VEGETABLES CONSUMPTION OF INDONESIAN POPULATION IN THE CONTEXT OF BALANCED NUTRITION : A Further An. Bul Penelit Kesehatan,. 2016;44(3):4-10.

16.Menteri Kesehatan RI. PMK No. 41 Tahun 2014 Pedoman Gizi Seimbang. Jakarta; 2014.

17. Yanto N, Verawati B, Muchtar D. Hubungan konsumsi buah dan sayur dengan kejadian gizi lebih pada tenaga kesehatan dan tenaga non kesehatan 1. J Ners Vol [Internet]. 2020;4(23):1-10. Available from: http://journal.universitaspahlawa n.ac.id/index.php/ners

18. Bey H, Awaliya P, Pradigdo SF, Nugraheni SA. KURANGNYA KONSUMSI BUAH DAN SAYUR SEBAGAI FAKTOR RISIKO KEJADIAN OVERWEIGHT PADA REMAJA PUTRI (Studi pada Mahasiswi Fakultas Kesehatan Masyarakat Universitas Diponegoro Semarang). J Kesehat Masy. 2019;8(1):272-80.

19.Eryani R, Sulistyiwati E, Sunarto, Aristiati K. Hubungan Konsumsi Buah Sayur dan Makanan Berlemak dengan Obesitas pada Ibu Rumah Tangga di Amongrogo Rw 3 Limpung Batang. J Ris Gizi. 2015;3(2):33- 40.

20.Wijaya GBR, Muliarta IM, Permana P. Faktor-faktor yang berpengaruh pada Indeks Massa Tubuh (IMT) pada anak Sekolah Menengah Atas (SMA) di Kecamatan Buleleng, Bali, Indonesia tahun 2016. Intisari Sains Medis. 2020;11(1):223.

21.Nugroho K, Mulyadi N, Masi G. Hubungan Aktivitas Fisik Dan Pola Makan Dengan Perubahan Indeks Massa Tubuh Pada Mahasiswa Semester 2 Programstudi Ilmu Keperawatan Fakultas Kedokteran. J Keperawatan UNSRAT. 2016;4(2):105746.

22.Rizky Putri V, Angkasa D, Nuzrina R. Konsumsi Fast Food, Soft Drink, Aktivitas Fisik, dan Kejadian Overweight Siswa Sekolah Dasar di Jakarta. Indones J Hum Nutr. 2017;4(1):47-57.

23.Kristiyandaru A, Cristina S, Wibowo S, Wahyudi H, Ashandi K, S HI, et al. Pendidikan Jasmani Sadarkan Arti Hidupku - Google Books [Internet]. Vol. 1. sidoarjo: zifatama jawara; 2020 [cited 2021 Jun 13]. Available from: https://www.google.co.id/books/e dition/Pendidikan_Jasmani_Sada rkan_Arti_Hidupku/sK4LEAAAQBAJ?hl=id\&gbpv=1\&dq=kurang+aktivitas+fisik\&printsec=front cover

24.Hastuti P. Genetika Obesitas [Internet]. Devi, editor. Yogyakarta: Gajah Mada University Press; 2019 [cited 2021 Jun 15]. Available from: https://www.google.co.id/books/e 
E-ISSN: 2808-5361 http://e-journal.fkmumj.ac.id/
Proceeding The First Muhammadiyah InternasionalPublic Health and Medicine Conference

dition/Genetika_Obesitas/Fl28DwAAQBAJ?hl=id\&gbpv=1\&dq=obat+steroid+obesitas\&pg=PA83 \&printsec=frontcover

25. Yulianti S, Eliyana Y. Jurnal sakti bidadari. 2021;IV(1).

26.Sunita A. Prinsip Dasar ILMU GIZI. Jakarta: Kompas Gramedia; 2010. 72-76 p.

27.HR S. Teknologi Kontrasepsi. Yogyakarta: Gajah Mada University Press; 2007. 8-51 p.

28.Badan Pengkajian dan Penerapan Teknologi. Outlook Teknologi Pangan 2016 Diversifikasi Pangan

Karbohidrat. Banten: Badan Pengkajian dan Penerapan Teknologi; 2016.

29.Pudjirahaju A. Pengawasan dan Mutu pangan. Jakarta: Kementerian Kesehatan RI; 2018.

30.Notoadmodjo. Perilaku Kesehatan dan Ilmu Perilaku. Jakarta: PT Rineka Cipta; 2007. 